\title{
AKURASI NILAI WAKTU IHTIYATH DALAM PERHITUNGAN AWAL WAKTU SALAT
}

\author{
Jayusman \\ Dosen Fakultas Syariah UIN Raden Intan Lampung \\ J1. Endro Suratmin Sukarame Bandar Lampung \\ email: jayusman@radenintan.ac.id
}

\begin{abstract}
Abstrak: Dalam perhitungan awal waktu salat secara umum biasanya ditambahkan waktu ihtiyath agar azan dikumandangkan ketika awal waktu salat itu telah benarbenar telah masuk. Misalnya ketika awal waktu salat Subuh; fajar Shadiq telah benarbenar terbit, ketika awal waktu salat Zuhur; matahari benar-benar telah tergelingir ke langit bagian barat, ketika awal waktu salat Maghri; matahari benar-benar sudah terbenam, dan ketika awal waktu Isya; syafaq benar-benar telah hilang. Adanya tambahan waktu ihtiyath berguna sebagai antisipasi agar daerah paling barat daerah tersebut dalam melaksanakan ibadah secara bersamaan dengan seluruh warga kota atau daerah tersebut. Para ulama Falak berbeda pendapat tentang nilai ihtiyath dalam perhitungan awal waktu salat. Bagaimanakan konstruksi pemikiran para ahli Falak tentang ihtiyath dalam penentuan awal waktu salat? Dan Bagaimanakah tinjauan ilmu Falak terkait efisiensi nilai ihtiyath dalam penentuan awal waktu salat? Dari paparan sebelumnya, dapatlah kita simpulkan sebagai berikut: Ulama Falak Tradisional dan ulama Dahulu cenderung memberikan nilai ihtiyath dalam perhitungan awal waktu yang besar. Hal ini karena jadwal salat yang mereka hisab cenderung untuk daerah atau kota tersebut dan daerah sekitarnya. Sedang ulama Falak sekarang memberikan nilai ihtiyath yang lebih kecil dengan pertimbangan keutamaan salat di awal waktu.Besaran ihtiyath dalam perhitungan awal waktu salat harus mempertimbangkan: luas daerah atau kota yang dihitung awal waktu salatnya dan acuan koordinat kota atau daerah yang dijadikan patokan perhitungan.
\end{abstract}

Kata Kunci: Ihtiyath, Awal Waktu Salat

\section{A. Pendahuluan}

Dalam perhitungan awal waktu salat dalam ilmu Falak terdapat waktu antisipatif yang dikenal dengan ihtiyath. Waktu ihtiyath ini merupakan antisipasi agar ibadah salat yang dilaksanakan pada waktu yang ditentukan-diyakini waktunya telah benar-benar masuk. Hal ini sangat urgen karena keyakinan masuknya waktu merupakan syarat sah ibadah salat yang dilaksanakan.

Landasan syar'i pensyariatan waktu ihtiyath ini antara lain hadis-hadis Nabi yang menegaskan tentang larangan pelaksanaan salat saat mata hari terbit, terbenam, dan istiwa (berkulminasi atas). Misalnya untuk menambah keyakinan salat Zuhur yang dilaksanakan benar-benar saat matahari telah tergelincir; bergeser ke arah barat setelah berkulminasi biasanya para ahli Falak dalam perhitungan awal waktu salat menambahkan yang dinamakan waktu ihtiyath.

Para ahli Falak berbeda pendapat dapat menerjemahkan waktu yang dibutuhkan seseorang untuk membaca lima puluh atau enam puluh ayat alQur'an. Perbedaan pendapat mereka tersebut dapat dijelaskan sebagai berikut: 
1. Jumhur ulama menyatakan bahwa waktu imsak itu adalah sepuluh menit sebelum awal waktu Subuh.

2. Noor Ahmad SS Jepara menyatakan bahwa waktu imsak itu adalah tiga belas menit sebelum awal waktu Subuh. ${ }^{1}$

3. Muhyidin Khazin menyatakan bahwa waktu imsak itu adalah delapan menit sebelum awal waktu Subuh. Dengan demikian, ketinggian Matahari pada waktu Imsak adalah $-22^{\circ}$.

Tanda-tanda waktu Subuh termasuk sulit diamati di antara tanda-tanda waktu salat lainnya, karena itu untuk menghindari batalnya puasa karena keterbatasan kita dalam mengobservasi fonemena alam yang berkaitan dengan masuknya waktu Subuh maka seyogyanya diberi batasan imsak untuk ihtiyath. ${ }^{3}$ Diperlukannya waktu imsak ini sebagai antisipasi sebelum masuknya awal waktu Subuh ketika seseorang itu masih makan sahur. Makan minum setelah masuknya waktu Subuh menyebabkan batalnya ibadah puasa yang bersangkutan.

Dalam perhitungan awal waktu salat secara umum biasanya ditambahkan waktu ihtiyath agar azan dikumandangkan ketika awal waktu salat itu telah benar-benar telah masuk. Misalnya ketika awal waktu salat Subuh; fajar Shadiq telah benar-benar terbit, ketika awal waktu salat Zuhur; matahari benar-benar telah tergelingir ke langit bagian barat, ketika awal waktu salat Maghri; matahari benar-benar sudah

1 Noor Ahmad SS, Syawariq al-Anwar, Kudus: madrasah Tasywiq ath-Thullab Salafiyah

${ }^{2}$ Muhyiddin Khazin, op.cit, h. 92

3 Ibnoe Zahid Abdo el-Moeid, Belajar Ilmu Hisab, http://rukyatulhilal.org/ diunduh pada padapada tanggal 4 Maret 2010 dan lih juga Jayusman, op.cit, h. 38 terbenam, dan ketika awal waktu Isya; syafaq benar-benar telah hilang.

Selanjutnya dalam pembuatan jadwal salat ada tambahan variabel yang harus diperhitungkan, yakni wilayah sebelah timur dari titik acuan koordinat kota atau daerah tersebut. Ketika telah dihitung awal waktu salat sebuah kota atau daerah, hakikatnya awal waktu salat itu berlaku berpatokan titik acuan koordinat kota atau daerah tersebut dan daerah di sebelah timurnya. Adapun untuk daerah sebelah barat titik acuan koordinat kota atau daerah tersebut belum masuk waktu. Dan akan berangsur-angsur masuk waktu bergeser ke arah barat dari titik tersebut. Adanya tambahan waktu ihtiyath berguna sebagai antisipasi agar daerah paling barat daerah tersebut dalam melaksanakan ibadah secara bersamaan dengan seluruh warga kota atau daerah tersebut.

Pemberian ihtiyath dalam perhitungan awal waktu salat itu harus efisien. Dengan perkataan bahwa jika ihtiyathnya terlalu banyak, maka akan kehilangan melaksanakan salat di awal waktu. Sebaliknya, jika ihtiyathnya kecil dikhawatirkan tidak mengkouver mereka yang berada di sebelah timur kota untuk salat bersamaan dengan dengan daerah lainnya di kota atau daerah tersebut.Inilah hal yang melatarbelakangi penelitian ini. Adapun rumusan permasalahan tulisan ini sebagai berikut: Bagaimanakan konstruksi pemikiran para ahli Falak tentang ihtiyath dalam penentuan awal waktu salat? Dan bagaimanakah tinjauan ilmu Falak terkait efisiensi nilai ihtiyath dalam penentuan awal waktu salat? 


\section{B. Pembahasan}

\section{Pengertian Ihtiyath}

Berikut marilah kita membahas lebih lanjut tentang apa yang dimaksud dengan ihtiyath.

1. M. Muslih mendefinisikan ihtiyath adalah angka pengaman yang ditambahkan pada hasil hisab waktu salat. Dengan maksud agar seluruh penduduk suatu kota, baik yang tinggal di ujung Timur dan Barat kota, dalam mengerjakan salat sudah benar-benar masuk waktu. ${ }^{4}$

2. Kementrian Agama RI menyatakan bahwa ihtiyath adalah suatu langkah pengamanan dalam menentukan waktu salat dengan cara menambahkan atau mengurangkan waktu agar tidak mendahului awal waktu salat dan tidak melampaui akhir waktu salat. ${ }^{5}$

3. Encup Supriatna menyatakan bahwa ihtiyath merupakan suatu langkah pengaman dengan menambah (untuk watu Zuhur, Asar, Magrib, Isa, dan Subuh) atau mengurangkan (untuk terbit/ Suruq) waktu agar jadwal salat tidak mendahuluinya atau melampaui akhir waktu. ${ }^{6}$

Dari definisi ihtiyath sebelumnya terlihat semuanya sama-sama menyatakan bahwa ihtiyath itu merupakan bentuk pengamanan pada perhitungan awal waktu salat agar

${ }^{4}$ M. Muslih, Penetapan Lintang dan Bujur Kab Dati II Batang (Tabkik di Pusat Kota Dan Pengarubnya Terbadap Arab Kiblat, Waktu Salat, dan Ibtiyath), (Pekalongan: STAIN Pekalongan, 1997) h. 43.

5 Depag RI , Pedoman Penentuan Jadwal Waktu Shalat Sepanjang Masa, (Jakarta: Depag RI, 1986), h. 10 dan lih juga, Badan Hisab Rukyat Depag, Almanak Hisab Rukyat, Jakarta: Proyek Pembinaan Badan Peradilan Agama Islam, h. 219

6 Encup Supriatna, Hisab Rukyat dan Aplikasinya, (Bandung: Refika Aditama, 2007), h. xiv seluruh kota; termasuk juga mereka yang bermukim di sebelah baratnya dalam melaksanakan salat sudah benarbenar masuk waktunya.

\section{Landasan Hukum}

Landasan syar'i pensyariatan waktu ihtiyath ini antara lain hadis-hadis Nabi yang menegaskan tentang larangan pelaksanaan salat saat mata hari terbit, terbenam, dan istiwa (berkulminasi atas). Ataupun hadis-hadis yang menerangkan awal waktu salat secara umum. Misalnya untuk menambah keyakinan salat Zuhur yang dilaksanakan benar-benar saat matahari telah tergelincir; bergeser ke arah barat setelah berkulminasi atau pun untuk memastikan waktu salat telah benarbenar masuk bagi mereka yang berada di sebelah barat kota atau daerah yang dihitung awal waktu salatnya, biasanya para ahli Falak dalam perhitungan awal waktu salat menambahkan yang dinamakan waktu ihtiyath.

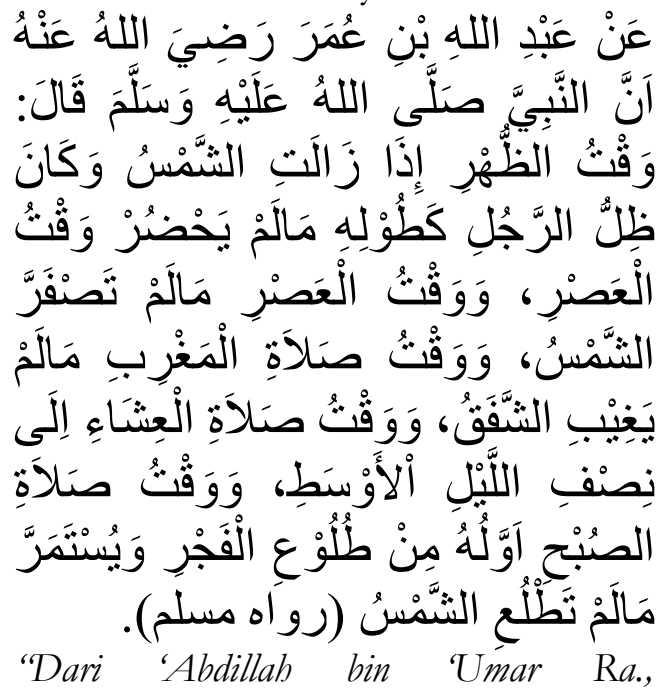
babwasanya Nabi saw bersabda: Waktu Zubur ialah bila Matahari sudah tergelincir (ke arah Barat), bingga bayang-bayang orang sama dengan panjangnya selama belum masuk waktu Asar. Akbir waktu Asar itu selama belum menguningnya Matahari, dan waktu salat Maghrib hingga sebelum bilangnya awan (mega) merah, dan waktu 
salat Isya ialah hingga tengah malam. Sedangkan waktu salat Subub itu mulai terbit fajar bingga sebelum terbit Matahari" (H.R. Muslim).

Hadis yang secara rinci dan detail menerangkan waktu-waktu salat.

عن جَابِرُ بْنُ عَبْدِ اللَّهِ قَالَ جَاءَ جِبْرِيلْ

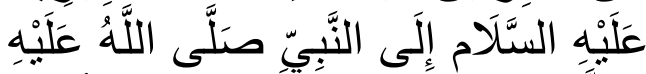

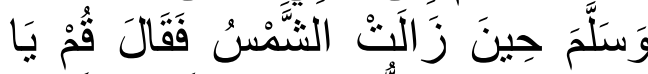

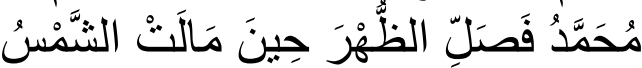

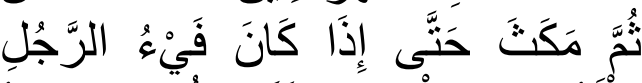

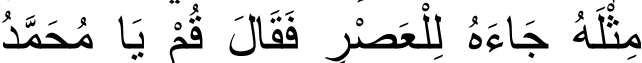

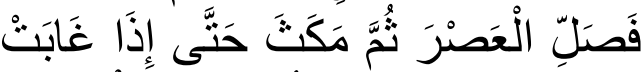

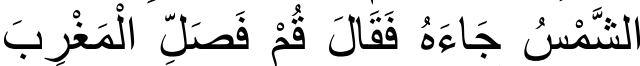

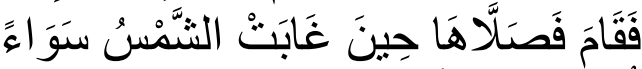

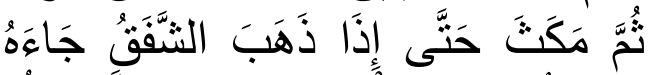

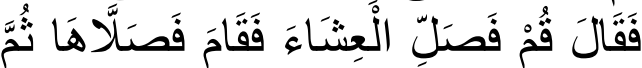

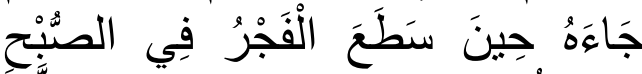

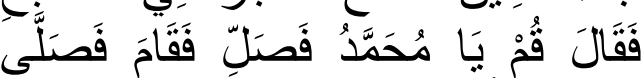

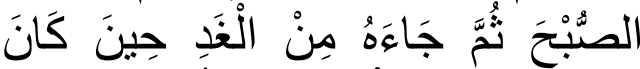

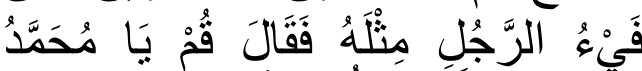

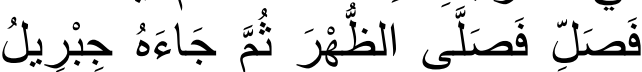

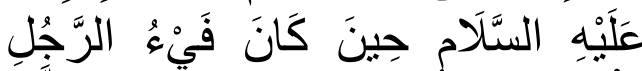

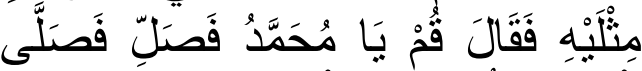

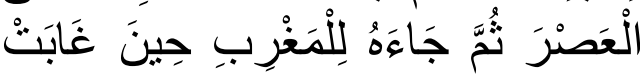

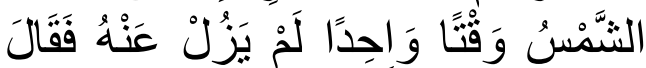

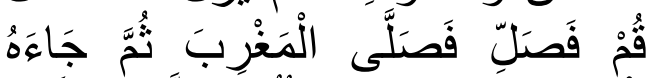

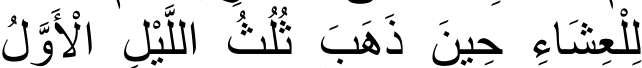

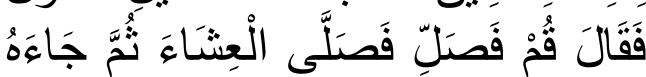

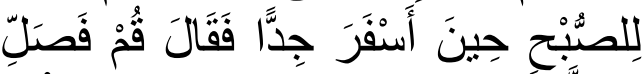

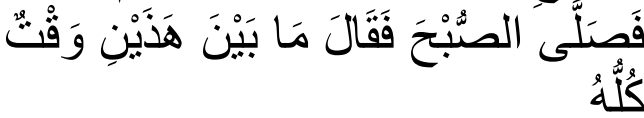

Dari Jabir bin Abdullah, bahwasanya Jibril datang kepada Nabi saw, lalu berkata

7 Lihat al-Sayyid al-Imam Muhammad bin Ismail al-Kahlani, Subul al-Salam, Juz I, hal. 106. kepadanya: Bangunlah dan salatlah, maka Nabi pun melakukan salat Dhubur pada saat matahari telab tergelincir. Kemudian datang pula Jibril kepada Nabi pada waktu Asar, lalu berkata : bangunlah dan salatlah, maka Nabi melakukan salat Asar pada saat bayangan matahari sama dengan panjang bendanya. Kemudian Jibril datang pula kepada Nabi waktu Maghrib, lalu berkata: Bangunlah dan bersalatlah, maka Nabi melakukan salat Maghrib, pada saat matahari telah terbenam. Kemudian Jibril datang lagi pada waktu Isya' serta berkata: Bangunlab dan bersalatlah, maka Nabi melakukan salat Isya, pada saat mega merah telah bilang. Kemudian datang pula Jibril pada waktu Subub, lalu berkata: Bangunlah dan bersalatlah, maka Nabi melakukan salat Subuh pada saat fajar shadiq telah terbit. Pada keesokan harinya Jibril datang lagi untuk waktu Zubur, Jibril berkata : Bangunlah dan salatlah, maka Nabi melakukan salat Zubur pada saat bayangan matahari yang berdiri telah menjadi panjang. Kemudian Jibril datang lagi pada waktu Asar pada saat bayangan matahari dua kali sepanjang dirinya. Kemudian datang lagi Jibril pada waktu Maghrib pada saat waktu beliau datang kemarin juga. Kemudian datang lagi Jibril pada waktu Isya, diketika telab berlalu separuh malam, atau sepertiga malam, maka Nabi pun melakukan salat Isya, Kemudian datang lagi Jibril diwaktu telah terbit fajar shadiq, lalu berkata: Bangunlah dan salatlah Subuh, sesudah itu Jibril berkata: Waktuwaktu di antara kedua waktu ini, itulah waktu salat.

Hadis-hadis tersebut merupakan hadis-hadis yang berbicara tentang batas-batas waktu salat lima waktu. Allah swt sungguh Maha Mengetahui dan penuh kasih sayang. Batas-batas waktu shalat tidak ditentukan berdasarkan jam, tapi didasarkan pada fenomena alam, sehingga sangat fleksibel. Misalnya ketika di suatu 
daerah matahari tenggelam pada jam 20 malam, maka ketika itulah waktu salat maghrib, begitu seterusnya. Ketentuan tersebut juga sangat membantu orangorang di pedalaman yang tidak mengenal jam.

\section{Ihtiyath Dalam Perhitungan Awal} Waktu Salat

Berapa besaran ihtiyath ketika melakukan perhitungan awal waktu salat? Perlu kiranya logika pemberian ihtiyath ini dijelaskan terlebih dahulu agar tidak terjadi ketidakjelasan tentang besarnya ihtiyath yang akan digunakan misalnya menggunakan ihtiyath yang terlalu besar atau mungkin mereka yang tidak memperhitungkan ihtiyath sama sekali. Di samping itu untuk dapat menetapkan besaran ihtiyath yang realistik dalam perhitungan jadwal salat untuk suatu kota atau daerah.

Perhitungan luas yang daerah yan dapat dicover dengan besaran waktu yang dijadikan pengaman (ihtiyath) itu dijelaskan sebagai berikut. Diasumsikan bahwa bola Bumi $360^{\circ}$ dengan kelilingnya di ekuator $40.000 \mathrm{~km}$. maka untuk $1^{\circ}$ busur jaraknya adalah: 40.000: $360 \times 1 \mathrm{~km}=111,1 \mathrm{~km}$.

Sehingga untuk 1 menit waktu sama dengan $111,11 \mathrm{~km}: 4=27,77 \mathrm{~km}$. Sehingga jika kita menggunakan ihtiyath 1 menit maka jangkauannya dari pusat kota (tempat yang dijadikan sebagai acuan koordinat geografis kota tersebut) sampai ke tepi barat kota sejauh $27,77 \mathrm{~km}^{8}{ }^{8}$

Kemenag dalam perhitungan awal waktu salat menggunakan waktu ihtiyath 2 menit sehingga mengkover daerah di sebelah barat kota sejauh $27,77 \mathrm{~km} \times 2=55,54 \mathrm{~km}{ }^{9}$

\footnotetext{
${ }^{8}$ Muslih, op.cit, h. 44

${ }^{9}$ Ibid, h. 45
}

Dengan demikian dapat diperhitungkan berapakah nilai ihtiyath yang akan digunakan untuk perhitungan sebuah jadwal salat. Jika jadwal tersebut diperuntukkan untuk sebuah kota yang besar yang daerahnya luas tentu saja nilai ihtiyathnya juga tentu saja lebih besar dibanding jika kita melakukan perhitungan waktu salat untuk kota yang relatif lebih kecil.

\section{Fungsi Waktu Ihtiyath}

Pemberian ihtiyath ini perlu dilakukan disebabkan adanya beberapa hal, sebagai berikut:

a. Adanya pembulatan-pembulatan dalam pengambilan data. Walaupun pembulatan itu sangat kecil. Demikian pula hasil akhir perhitungan yang diperoleh; yang biasanya dalam satuan detik, lalu disederhanakan dan dilakukan pembulatan sampai satuan menit.

b. Jadwal salat kadang diberlakukan dalam jangka waktu yang sangat lama; bahkan diklaim untuk selamalamanya, sedang data-data yang digunakan diambil dari data tahun tertentu ataupun perata-rataan dari data beberapa tahun. Padahal datadata Mata hari itu secara rilnya dari tahun ke tahun (baca waktu ke waktu) terdapat perubahan walaupun sangat kecil. Perubahan ini tentu saja akan berpengaruh terhadap perhitungan jadwal salat, meskipun pengaruhnya sedikit sekali.

c. Penentuan data lintang dan bujur suatu kota biasa diukur pada titik yang dijadikan markaz di pusat kota (pada saat itu). Waktu ihtiyath diperlukan untuk mengantisipasi daerah di sebelah baratnya (daerah sebelah timur mengalami/memasuki awal waktu salat lebih dahulu atau 
lebih awal daripada daerah yang di sebelah baratnya).

d. Bisanya sebuah jadwal salat untuk suatu kota juga dipergunakan oleh daerah di sekitarnya yang berdekatan dan tidak terlalu jauh jaraknya. Seperti jadwal salat untuk kota kabupaten dipergunakan oleh kota-kota kecamatan sekitarnya. Agar tidak terjadi kekeliruan dalam penentuan awal waktu salat bagi daerah di sekitar kota peruntukannya, jadwal salat tadi diperlukan waktu ihtiyath. ${ }^{10}$

e. Mengcover daerah yang memiliki tekstur ketinggian yang berbeda antara satu sisi dengan sisi lainnya. Waktu Ihtiyath untuk mengatisipasi kota yang teksturnya tidak datar; ada bagian kota yang terdiri dari dataran tinggi sedangkan bagian yang lainnya adalah dataran rendah. Perimbangan waktu untuk kedua bagian kota tersebut (agar salat tersebut tidak lebih cepat atau terlalu lambat). Ketinggian tempat ini terkait dengan $h$ (ketinggian) Mata hari; terbit dan atau terbenam Mata hari di suatu tempat). Pada daerah dataran tinggi, akan menyaksikan atau mengalami saat Mata hari terbenam belakangan dibandingkan mereka yang tinggal di daerah dataran rendah. Dan akan menyaksikan atau mengalami saat Mata hari terbit lebih dahulu dibandingkan mereka yang tinggal di daerah dataran rendah. Terkait dengan ketinggian tempat ini terdapat perbedaan pendapat di kalangan ahli ilmu Falak, sebagai berikut:

1). Ketinggian tempat itu diukur dari permukaan laut. Terlepas daerah atau tempat tersebut teksturnya

10 Ibid, h. 37-38 datar atau mungkin merupakan perbukitan/dataran tinggi. ${ }^{11}$

2). Daerah tersebut merupakan perbukitan/dataran tinggi sehingga memiliki ufuk yang lebih rendah. Ini berdampak pada ketinggian Mata hari pada waktu terbit atau terbenam. Seperti kota Semarang; daerah bagian utaranya dataran rendah karena berada di dekat pantai sedang daerah selatannya merupakan daerah perbukitan. Pendapat ini yang dipilih oleh badan Hisab Rukyat Kota Bandung dalam salah satu rilisnya.

5. Besaran Nilai Ihtiyath Dalam Perhitungan Sebuah Jadwal Salat

Dalam pemberian waktu ihtiyath, terdapat perbedaan di kalangan ahli Falak. Di antara mereka ada yang memberikan waktu ihtiyath sebesar dua menit, tiga menit, empat menit, dan sebagainya. Perbedaan itu dapat dilihat sebagai berikut:

a. Kalangan pesantren tertentu tidak mencantumkan waktu ihtiyath dalam jadwal salat yang dibuatnya. Pelaksanaan azan sebagai pertanda masuknya awal waktu salat dilaksanakan sesuai dengan waktu yang sebenarnya. Jadwal yang dibuatnya ini hanya bersifat internal; hanya

${ }^{11}$ Jika suatu daerah itu teksturnya datar walaupun ia merupakan daerah yang berada pada dataran tinggi (dihitung dari permukaan laut), maka ketinggian daerah tersebut tidak berpengaruh pada perhitungan erendahan ufuk karena ufuk di tempat atau daerah tersebut relatif datar. Namun pada daerah perbukitan/dataran tinggi, maka akan memiliki ufuk yang lebih rendah. 
diberlakukan di pondok pesantren yang bersangkutan. $^{12}$

b. Noor Ahmad SS menggunakan Ihtiyath 3 menit untuk setiap perhitungan awal waktu salat. Kecuali untuk awal waktu Zuhur, ia menggunakan ihtiyath 4 menit. ${ }^{13}$

c. Ibnoe Zahid Abdo el-Moeid dalam Imsakiah Ramadan $1430 \quad \mathrm{H}$ menggunakan Ihtiyath 2 menit untuk setiap perhitungan awal waktu salat. Kecuali untuk awal waktu Zuhur, ia menggunakan ihtiyath 4 menit. $^{14}$

d. Muhyidin Khazin menyatakan bahwa Ihtiyath dalam penentuan awal waktu salat sebenar 1 sampai 2 menit. ${ }^{15}$ Merupakan pembulatan hasil akhir perhitungan awal waktu salat tersebut. Jika bilangan detik hasil akhir perhitungan awal waktu salat itu kecil, maka nilai ihtiyathnya mendekati 2 menit. Sedangkan apabila bilangan detiknya besar, maka nilai ihtiyathnya mendekati 1 menit.

e. Saadoeddin Djambek menggunakan nilai ihtiyath 2 menit.

f. Abdur Rachim menggunakan nilai ihtiyath 2 menit.

g. Kementerian Agama RI menggunakan nilai ihtiyath 2 menit.

h. Zul Efendi; ahli Falak dari Bukittinggi, sumatera Barat, murid

12 Wawancara dengan Slamet Hambali, Semarang 06 November 2010

${ }^{13}$ Noor Ahmad SS, Risälah al-Falak Nur al-Anwar, Kudus: Madrasah Taswiquththullab Salafi, 1986.

${ }^{14}$ Ibnoe Zahid Abdo el-Moeid, Jadwal Imsakiah Ramadan 1430 H untuk Kota Bandar Lampung, geocitis.com diakses pada tanggal 6 November 2009

15 Muhyiddin Khazin, Ilmu Falak dalam Teori dan Praktik, Jogjakarta: Buana Pustaka, 2008, h. 82
Arius Syaikhi, ${ }^{16}$ menggunakan ihtiyath satu atau dua menit dalam jadwal salat yang ia buat dan banyak dipakai di berbagai kota di Sumatera Barat. ${ }^{17}$ Besaran ihtiyath yang digunakan tergantung besar kecilnya kota yang dihitung jadwal salatnya tersebut. Misalnya untuk kota Bukittinggi yang merupakan sebuah kotamadya yang luas wilayahnya kecil digunakan ihtiyath sebesar 1,5 menit sedangkan jadwal salat untuk kota Padang yang merupakan ibukota propinsi Sumatera Barat yang luas wilayahnya relatif besar menggunakan ihtiyath sebesar 2 menit. ${ }^{18}$

${ }^{16}$ Arius Syaikhi adalah nama ahli Falak yang menghisab jadwal salat Jadwal waktu Salat untuk selama-lamanya untuk daerah Tanjung Karang, Teluk Betung, Panjang, Metro dan Menggala yang dihisab oleh Arius Syaikhi Payakumbuh. Sedang Payakumbuh, nama sebuah kota di propinsi Sumatera Barat tempat ia berasal. Informasi yang diperoleh tentang biografinya sangat terbatas. Menurut penuturan Muswardi Taher, seorang mubaligh yang cukup dikenal di propinsi Lampung. Ketika berdakwah ke berbagai daerah di propinsi Lampung jadwal ini banyak ditemukan di masjid-masjid yang dikunjunginya tersebut. Bahkan ketika melawat ke suatu daerah di pulau Kalimantan,ditemukan jadwal yang dihisab Arius Syaikhi untuk daerah di Kalimantan tersebut. Wawancara tanggal 2 Agustus 2010. Sepengetahuan penulis waktu penulis kecil di Bukittinggi, Sumatera Barat tahun 1980-an jadwal salat yang dihisab oleh Arius Syaikhi ini telah digunakan secara luas di Sumatera Barat. Menurut penuturan $\mathrm{Zul}$ Efendi; salah seorang murid Arius Syaikhi; dosen ilmu Falak STAIN Djamil Djambek (Bukittinggi) jadwal salat oleh Arius Syaikhi baru diperbarui oleh Zul Efendi sejak 20072008 lalu. Jadi sampai tahun 2006 jadwal salat yang dihisab oleh Arius Syaikhilah yang digunakan di masyarakat pada umumnya. Wawancara dengan Zul Efendi tanggal 5 Maret 2010.

17 Wawancara dengan Zul Efendi tanggal 5 Maret 2010.

18 Ibid 
i. Muhammadiyah dalam perhitungan awal waktu salat menggunakan ihtiyath 1-2 menit. ${ }^{19}$

Perbedaan dalam pemberian nilai atau besaran ihtiyath dalam perhitungan awal waktu salat ini terkait dengan perbedaan dalam pemaknaan ayat-ayat dan hadis dalam penentuan awal waktu salat. Yakni terkait pemberian waktu antisipatif agar pengerjaan saat benar-benar setelah masuknya waktu (yang terkait dengan fenomena matahari dalam pergerakan semu hariannya).

Selain itu perbedaan ini juga terkait juga dengan pemberian waktu antisipatif bagi mereka yang berda di sebelah barat dari titik koordinat kota yang dihisab awal waktu salatnya tersebut. Serta kebiasaan sebuah jadwa salat biasanya juga digunakan untuk daerah-daerah di sekitar kota atau daerah peruntukannya.

6. Waktu Imsak: Ihtiyath Dalam Pelaksanaan Ibadah Puasa Ramadan

Waktu Imsak dalam pelaksanaan puasa bulan Ramadan adalah waktu Ihtiyath. Waktu Imsak adalah waktu tertentu sebelum Subuh, saat kapan biasanya seseorang mulai berpuasa. ${ }^{20}$ Jeda waktu tersebut untuk kehatihatian. Ini tidaklah bententangan dengan sunnahnya mengakhirkan sahur sebagaimana banyak diriwayatkan dalam hadis dan tersirat dalam alQur'an surat al-Baqarah ayat ke 187.

19 Tim Majelis Tarjih dan Tajdid Pimpinan Pusat Muhammadiyah, Pedoman Hisab Muhammadiyah, Yogyakarta: Majelis Tarjih dan Tajdid Pimpinan Pusat Muhammadiyah, 2009, cet.ke-2, h. 58

${ }^{20}$ Badan Hisab dan Rukyat, op.cit, h. 221
Kekhasan perhitungan awal waktu salat dalam jadwal imsakiah ${ }^{21}$ dan perhitungan awal waktu salat pada bulan Ramadan adalah terdapatnya waktu imsak dan berbuka. Waktu berbuka adalah sama dengan awal waktu salat Magrib. Adapun waktu imsak (awal waktu memulai ibadah puasa sebelum masuknya awal waktu salat Subuh). Jadi kita cukup menambahkan kolom waktu imsak untuk jadwal imsakiah dari jadwal awal waktu salat biasa.

Mengenai penentuan waktu imsak ini, para ulama berbeda pendapat dalam memaknai hadis Rasululah yang menyatakan waktu imsak itu kira-kira sama dengan waktu yang dibutuhkan untuk membaca lima puluh ayat alQur'an. Hal tersebut dijelaskan dalam hadis Nabi berikut:

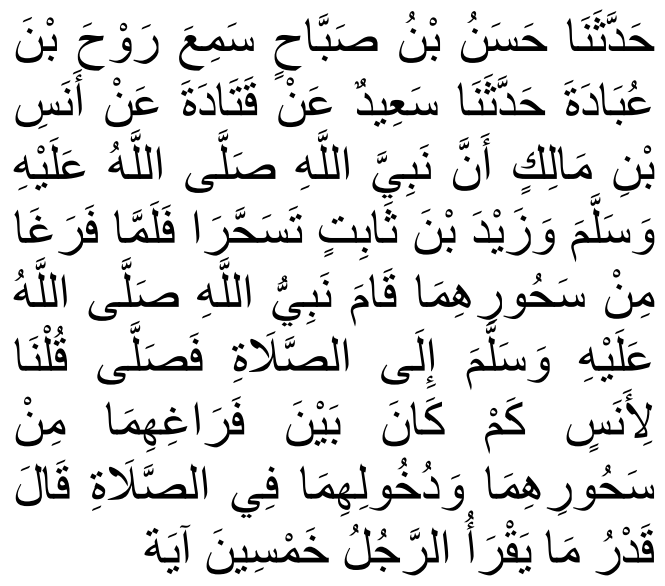

Telah menceritakan kepada kami Hasan bin Shabbah telah mendengar Raub bin 'Ubadah telah menceritakan kepada kami Sa'id dari Qatadab dari Anas bin Malik, babwa Nabi shallallabu 'alaihi wasallam dan Zaid bin Tsabit makan sabur bersama. Setelah keduanya selesai makan sabur, beliau lalu bangkit melaksanakan salat." Kami bertanya kepada Anas, "Berapa rentang waktu antara selesainya makan sabur hingga

21 Jadwal salat yang diedarkan untuk panduan pelaksanaan ibadah salat dan puasa Ramadan. 
keduanya melaksanakan salat?" Anas bin Malik menjawab, "Kira-kira waktu seseorang membaca lima puluh ayat."122

Di antara pendapat ulama itu adalah sebagai berikut:

a. Jumhur ulama Falak menyatakan bahwa waktu imsak itu adalah sepuluh menit sebelum awal waktu Subuh.

b. Noor Ahmad SS Jepara menyatakan bahwa waktu imsak itu adalah tiga belas menit sebelum awal waktu Subuh. $^{23}$

c. Muhyidin Khazin menyatakan bahwa waktu imsak itu adalah delapan menit sebelum awal waktu Subuh. Dengan demikian, ketinggian Mata hari pada waktu Imsak adalah $-22^{\circ} .^{24}$

d. Kitab al-MukbtAsar al-Mubadzdzab menyatakan waktu imsak itu dua belas menit sebelum Subuh.

e. Zuber Umar al-Jailani; pengarang kitab al-Khulashah al-Wafiyah menyatakan bahwa waktu imsak itu tujuh sampai dengan delapan sebelum Subuh.

f. Saadoeddin Djambek menyatakan waktu imsak itu adalah sepuluh menit sebelum awal waktu Subuh.

g. Turaichan Adjhuri memberikan 1314 menit waktu ihtiyath sebelum Subuh. ${ }^{25}$

h. Kementerian Agama RI dalam masalah penentuan waktu Imsak mengguanakan pendapat Jumhur ulama Falak yakni sepuluh menit sebelum awal waktu Subuh.

22 Ibid, Hadis No 542

23 Noor Ahmad SS, Syawariq al-Anwar, Kudus: madrasah Tasywiq ath-Thullab Salafiyah

${ }^{24}$ Muhyiddin Khazin, Ilmu Falak dalam Teori dan Praktik, Jogjakarta: Buana Pustaka, 2008, h. 92

25 Kalender Menara Kudus tahun $2011 \mathrm{M} / 1432 \mathrm{H}$
Diperlukannya waktu imsak ini sebagai antisipasi telah masuknya waktu Subuh ketika seseorang itu masih makan sahur. Makan minum setelah masuknya waktu Subuh menyebabkan batalnya ibadah puasa yang bersangkutan. Tanda-tanda waktu Subuh termasuk sulit diamati diantara tanda-tanda waktu salat lainnya, karena itu untuk menghindari batalnya puasa karena keterbatasan kita dalam mengobservasi fonemena alam yang berkaitan dengan masuknya waktu Subuh maka seyogyanya diberi batasan Imsak untuk ihtiyath. ${ }^{26}$

7. Pengaruh Besaran Ihtiyath Terhadap Perbedaan Jadwal Salat

Kadang ditemui jadwal salat; dalam hal ini termasuk juga imsakiah, untuk suatu daerah yang tidak persis sama antara satu dengan lainnya. Walaupun perbedaannya relatif kecil yakni antara satu-dua menit. Menurut Muhyiddin Khazin selain karena besaran ihtiyath, perbedaan ini disebabkan antara lain oleh:

a. Perbedaan data koordinat yang dijadikan acuan.

Perbedaan pengambilan data koordinat ini kemungkinan karena beberapa faktor:

1). Perbedaan acuan koordinat. Adakalanya koordinat suatu kota itu dihitung dari kantor kepala daerahnya, atau monumen yang dijadikan lanmard kota, atau adapula yang dihitung berdasarkan hasil perhitungan titik pusat kota atau daerah tersebut dihitung dari bagian daerah yang paling timur dan barat.

2). Adanya pengembangan atau perluasan kota atau daerah.

26 Ibnoe Zahid Abdo el-Moeid, Belajar Ilmu Hisab, http:/ / rukyatulhilal.org/ diakses pada tanggal 4 Maret 2010 
3). Perbedaan sumber pengambilan data. Adakalanya data koordinat itu diambil dari peta yang dikeluarkan oleh institusi atau lembaga yang berbeda. Biasanya karena letak suatu kota pada peta tidak persis pada lintang atau bujur tertentu, maka dilakukan interpolasi pada peta tersebut. Contoh perbedaan dalam pengambilan data koordinat daerah ini adalah pengambilan data koordinat kota Bandar Lampung dalam berbagai Imsakiah Ramadan $1430 \mathrm{H}$ untuk kota Bandar Lampung yang lalu: Badan Hisab Rukyat Kementerian Agama $\Phi-5^{\circ}$ 25' LS $\lambda 105^{\circ}$ 17'BT, Fakultas Syari'ah IAIN Raden Intan Lampung $\Phi-5^{\circ} 26^{\prime} \mathrm{LS} \quad \lambda 105^{\circ}$ 16'BT, dan Ibnoe Zahid Abdo elMoeid $\Phi-5^{\circ} 26^{\prime}$ LS $\lambda 105^{\circ} 14^{\prime} B T$.

b. Perbedaan rumus perhitungan yang digunakan.

Perhitungan atau penentuan awal waktu salat atau jadwal salat yang lazim digunakan Indonesia ada dua macam. Yakni perhitungan yang dijadikan pedoman oleh Kemenag (menggunakan rumus yang tidak memperhitungkan ketinggian tempat). Dan perhituangan yang menggunakan rumus dengan ketinggian tempat tersebut dari permukaan laut.

Perbedaan alat perhitungan yang digunakan, terdapat kesalahan dalam melakukan perhitungan, dan data yang digunakan. ${ }^{27}$ Dalam melakukan perhitungan awal waktu salat dapat dilakukan secara manual, menggunakan kalkulator, atau dibantu dengan perangkat komputer yang telah terprogram ataupun tidak. Perhitungan secara manual cukup memakan waktu.

27 Muhyiddin Khazin, 99 Tanya Jawab Masalab Hisab \& Rukyat, Yogyakarta: Ramadan Press, h 45-46
Biasanya dalam perhitungan secara manual kerap dilakukan pembulatan atau penyederhanaan data untuk memudah perhitungan. Untuk membantu perhitungan dapat menggunakan kalkulator. Namun tetap saja ada keterbatasan perhitungan dengan kalkulator, misalnya kesulitan mengentri rumus-rumus atau data yang panjang. Data perhitungan yang biasanya merupakan bilangan desimal; ditampilkan hanya sebesar digit dari kalkulator tersebut. Adapun perhitungan dengan dibantu dengan perangkat komputer dalam penyajian datanya memiliki ketelitian yang tinggi.

Penyebab perbedaan jadwal salat lainnya adalah karena faktor kesalahan yang bersifat human error dan kesalahan data. Kesalahan yang bersifat human error misalnya kesalahan basib (orang yang melakukan perhitungan) dalam pengambilan data dan kesalahan dalam pengambilan; penggunaan ataupun pengerjaan rumus. Kesalahan dapat juga karena kesalahan data yang terdapat dalam buku pedoman perhitungan, mungkin salah cetak yang dilakukan oleh pihak penerbit atau percetakan yang tidak dikoreksi oleh penulisnya. Ataupun kesalahan itu berasal dari penulisnya sendiri.

Faktor selanjutnya adalah penggunaan data-data yang bersifat tetap, tidak berubah oleh hasib juga dalam menjadi faktor penyebab jadwal salat ketika disandingkan dengan perhitungan yang menggunakan data yang bersifat aktual, riil, sebenarnya. Dalam perhitungan awal waktu salat biasanya yang dibutuhkan adalah data eqution of time dan deklinasi Mata hari. Data eqution of time dan deklinasi Mata hari yang digunakan lazimnya adalah data keduanya untuk perhitungan awal waktu Zuhur. Data tersebut digunakan juga untuk 
perhitungan waktu-waktu salat yang lain pada hari tersebut (tidak menggunakan data ril masing-masing waktu salat. Dengan alasan perbedaannya tidak banyak; sangat kecil sekali. Data deklinasi biasanya perata-rataan dari data deklinasi Mata hari empat tahunan.

Dalam penelitian penulis dengan kawan-kawan yang berjudul Perbedaan Jadwal Imsakiah Ramadan $1430 \mathrm{H}$ Untuk Kota Bandar Lampung pada tahun 2010 salah satu temuannya adalah bahwa penyebab perbedaan jadwal imsakiah Ramadan $1430 \mathrm{H}$ Untuk Kota Bandar Lampung adalah perbedaan nilai ihtiyath yang digunakan hasib. Secara umum ihtiyath yang digunakan dalam perhitungan awal waktu salat oleh para ahli Falak adalah dua menit. Tapi dalam penelitian tersebut, terdapat ahli Falak yakni Ibnoe Zahid Abdo el-Moeid yang menggunakan ihtiyath senilai empat menit untuk awal waktu salat Zuhur. Sehingga jadwal Imsakiah yang dihasilkan juga berbeda. ${ }^{28}$

8. Konstruksi Pemikiran Para Ahli Falak Tentang Ihtiyath Dalam Penentuan Awal Waktu Salat

Pemikiran ulama Falak tentang nilai ihtiyath dalam penentuan awal waktu salat, sebagai berikut:

a. Kalangan pesantren tertentu tidak mencantumkan waktu ihtiyath dalam jadwal salat yang dibuatnya. Pelaksanaan azan sebagai pertanda masuknya awal waktu salat dilaksanakan sesuai dengan waktu yang sebenarnya. Jadwal yang dibuatnya ini hanya bersifat internal; hanya

28 Jayusman $\mathrm{dkk}$, Jadwal Imsakiah Ramadan 1430 H Untuk Kota Bandar Lampung, Penelitian Kompetitif, IAIN Raden Intan 2010 diberlakukan di pondok pesantren yang bersangkutan. $^{29}$

b. Noor Ahmad SS menggunakan Ihtiyath 3 menit untuk setiap perhitungan awal waktu salat. Kecuali untuk awal waktu Zuhur, ia menggunakan ihtiyath 4 menit. ${ }^{30}$

c. Ibnoe Zahid Abdo el-Moeid dalam Imsakiah Ramadan $1430 \quad \mathrm{H}$ menggunakan Ihtiyath 2 menit untuk setiap perhitungan awal waktu salat. Kecuali untuk awal waktu Zuhur, ia menggunakan ihtiyath 4 menit. $^{31}$

d. Muhyidin Khazin menyatakan bahwa Ihtiyath dalam penentuan awal waktu salat sebenar 1 sampai 2 menit. $^{32}$

e. Saadoeddin Djambek menggunakan nilai ihtiyath 2 menit.

f. Abdur Rachim menggunakan nilai ihtiyath 2 menit.

g. Kementerian Agama RI menggunakan nilai ihtiyath 2 menit.

h. Zul Efendi; Besaran ihtiyath yang digunakan tergantung besar kecilnya kota yang dihitung jadwal salatnya tersebut. Misalnya untuk kota Bukittinggi yang merupakan sebuah kotamadya yang luas wilayahnya kecil digunakan ihtiyath sebesar 1,5 menit sedangkan jadwal salat untuk

29 Wawancara dengan Slamet Hambali, Semarang 06 November 2010

${ }^{30}$ Noor Ahmad SS, Risälab al-Falak Nur al-Anwar, Kudus: Madrasah Taswiquththullab Salafi, 1986.

${ }^{31}$ Ibnoe Zahid Abdo el-Moeid, Jadwal Imsakiah Ramadan 1430 H untuk Kota Bandar Lampung, geocitis.com diakses pada tanggal 6 November 2009

32 Muhyiddin Khazin, Ilmu Falak dalam Teori dan Praktik, Jogjakarta: Buana Pustaka, 2008, h. 82 
kota Padang yang merupakan ibukota propinsi Sumatera Barat yang luas wilayahnya relatif besar menggunakan ihtiyath sebesar 2 menit. ${ }^{33}$

i. Muhammadiyah dalam perhitungan awal waktu salat menggunakan ihtiyath 1-2 menit. ${ }^{34}$

Data besaran nilai ihtiyath tersebut dapat disajikan dalam tabel berikut:

Tabel

Nilai Ihtiyath Penenetuan Awala Waktu Salat

\begin{tabular}{|c|c|c|}
\hline No & $\begin{array}{l}\text { Nilai } \\
\text { Ihtiyath }\end{array}$ & $\begin{array}{l}\text { Pendapat Ahli } \\
\text { Falak/ Kelompok }\end{array}$ \\
\hline 1 & - & $\begin{array}{l}\text { Kalangan pesantren } \\
\text { tertentu }\end{array}$ \\
\hline \multirow[t]{2}{*}{2} & $\begin{array}{l}1,5 \text { menit } \\
\text { (kota } \\
\text { kecil) }\end{array}$ & \multirow[t]{2}{*}{ Zul Efendi } \\
\hline & $\begin{array}{l}2 \text { menit } \\
\text { (kota } \\
\text { besar) }\end{array}$ & \\
\hline \multirow[t]{5}{*}{3} & \multirow[t]{5}{*}{2 menit } & Muhyidin Khazin \\
\hline & & $\begin{array}{l}\text { Saadoeddin } \\
\text { Djambek }\end{array}$ \\
\hline & & Abdur Rachim \\
\hline & & $\begin{array}{l}\text { Kementerian } \\
\text { Agama RI }\end{array}$ \\
\hline & & Muhammadiyah \\
\hline \multirow[t]{4}{*}{4} & 2 menit & \multirow{2}{*}{$\begin{array}{l}\text { Ibnoe Zahid Abdo } \\
\text { el-Moeid }\end{array}$} \\
\hline & $\begin{array}{l}4 \text { menit } \\
\text { (Zuhur) }\end{array}$ & \\
\hline & 3 menit & \multirow[t]{2}{*}{ Noor Ahmad SS } \\
\hline & $\begin{array}{l}4 \text { menit } \\
\text { (Zuhur) }\end{array}$ & \\
\hline
\end{tabular}

Apabila diasumsikan bahwa bola Bumi $360^{\circ}$ dengan kelilingnya di ekuator $40.000 \mathrm{~km}$. maka untuk $1^{\circ}$

33 Ibid

34 Tim Majelis Tarjih dan Tajdid Pimpinan Pusat Muhammadiyah, Pedoman Hisab Muhammadiyah, Yogyakarta: Majelis Tarjih dan Tajdid Pimpinan Pusat Muhammadiyah, 2009, cet.ke-2, h. 58 busur jaraknya adalah: 40.000: $360 \times 1$ $\mathrm{km}=111,1 \mathrm{~km} \cdot 1^{\circ}$ busur sama dengan 4 menit waktu. Maka untuk 1 menit waktu sama dengan 111,11 km: $4=$ $27,77 \mathrm{~km}$. Sehingga jika kita menggunakan ihtiyath 1 menit maka jangkauannya dari pusat kota (tempat yang dijadikan sebagai acuan koordinat geografis kota tersebut) sampai ke tepi barat kota sejauh 27,77 km.

Maka pemikiran ulama Falak tentang waktu ihtiyath dalam perhitungan awal waktu salat, dapat dijelaskan bahwa ihtiyath perhitungan awal waktu salat tanpa ihtiyath hanya diperuntukkan digunakan untuk daerah atau tempat yang menjadi markaz perhitungan. Adapun ihtiyath 1 menit mengcover daerah sebelah barat markas sejauh $27,77 \mathrm{~km}$. Ihtiyath 1,5 menit mengcover daerah sebelah barat markas sejauh 41,655 km. Sedangkan ihtiyath 2 menit mengcover daerah sebelah barat markas sejauh $55,54 \mathrm{~km}$. Lalu ihtiyath 3 menit mengcover daerah sebelah barat markas sejauh $83,31 \mathrm{~km}$. terakhir, ihtiyath ihtiyath 4 menit mengcover daerah sebelah barat markas sejauh 111,08 km.

Sebagaimana tabel berikut: 
Nilai Ihtiyath dan Cakupan Wilayah

\begin{tabular}{|c|c|c|c|}
\hline No & $\begin{array}{l}\text { Nilai } \\
\text { Ihtiyath }\end{array}$ & & $\begin{array}{l}\text { Pendapat } \\
\text { Ahli } \\
\text { Falak/ } \\
\text { Kelompok }\end{array}$ \\
\hline 1 & - & $\begin{array}{l}0 \times 27,77= \\
0\end{array}$ & $\begin{array}{l}\text { Kalangan } \\
\text { pesantren } \\
\text { tertentu }\end{array}$ \\
\hline \multirow[t]{2}{*}{2} & $\begin{array}{l}1,5 \text { menit } \\
\text { (kota } \\
\text { kecil) }\end{array}$ & $\begin{array}{l}1,5 \\
27,77= \\
41,655\end{array}$ & \multirow[t]{2}{*}{ Zul Efendi } \\
\hline & $\begin{array}{l}2 \text { menit } \\
\text { (kota } \\
\text { besar) }\end{array}$ & $\begin{array}{l}2 \times 27,77= \\
55,54\end{array}$ & \\
\hline \multirow[t]{5}{*}{3} & \multirow[t]{5}{*}{2 menit } & $\begin{array}{l}2 \times 27,77= \\
55,54\end{array}$ & $\begin{array}{l}\text { Muhyidin } \\
\text { Khazin }\end{array}$ \\
\hline & & $\begin{array}{l}2 \times 27,77= \\
55,54\end{array}$ & $\begin{array}{l}\text { Saadoeddin } \\
\text { Djambek }\end{array}$ \\
\hline & & $\begin{array}{l}2 \times 27,77= \\
55,54\end{array}$ & $\begin{array}{l}\text { Abdur } \\
\text { Rachim }\end{array}$ \\
\hline & & $\begin{array}{l}2 \times 27,77= \\
55,54\end{array}$ & $\begin{array}{l}\text { Kementerian } \\
\text { Agama RI }\end{array}$ \\
\hline & & $\begin{array}{l}2 \times 27,77= \\
55,54\end{array}$ & $\begin{array}{l}\text { Muhammadiy } \\
\text { ah }\end{array}$ \\
\hline \multirow[t]{2}{*}{4} & 2 menit & $\begin{array}{l}2 \times 27,77= \\
55,54\end{array}$ & \multirow{2}{*}{$\begin{array}{lr}\text { Ibnoe } & \text { Zahid } \\
\text { Abdo } & \text { el- } \\
\text { Moeid } & \end{array}$} \\
\hline & $\begin{array}{l}4 \text { menit } \\
\text { (Zuhur) }\end{array}$ & $\begin{array}{l}4 \times 27,77= \\
111,08\end{array}$ & \\
\hline \multirow[t]{2}{*}{5} & 3 menit & $\begin{array}{l}3 \times 27,77= \\
83,31\end{array}$ & \multirow[t]{2}{*}{$\begin{array}{l}\text { Noor Ahmad } \\
\text { SS }\end{array}$} \\
\hline & $\begin{array}{l}4 \text { menit } \\
\text { (Zuhur) }\end{array}$ & $\begin{array}{l}4 \times 27,77= \\
111,08\end{array}$ & \\
\hline
\end{tabular}

9. Tinjauan Ilmu Falak Terkait Efisiensi Nilai Ihtiyath Dalam Penentuan Awal Waktu Salat

Fungsi dari pemberian ihtiyath dalam perhitungan awal waktu salat disebabkan adanya beberapa hal, sebagai berikut:

a. Terkadang terdapat adanya pembulatan-pembulatan dalam pengambilan data. Walaupun pembulatan itu sangat kecil. Demikian pula hasil akhir perhitungan yang diperoleh; yang biasanya dalam satuan detik, lalu disederhanakan dan dilakukan pembulatan sampai satuan menit.

b. Jadwal salat kadang diberlakukan dalam jangka waktu yang sangat lama; bahkan diklaim untuk selamalamanya, sedang data-data yang digunakan diambil dari data tahun tertentu ataupun perata-rataan dari data beberapa tahun. Padahal datadata Mata hari itu secara rilnya dari tahun ke tahun (baca waktu ke waktu) terdapat perubahan walaupun sangat kecil. Perubahan ini tentu saja akan berpengaruh terhadap perhitungan jadwal salat, meskipun pengaruhnya sedikit sekali.

c. Penentuan data lintang dan bujur suatu kota biasa diukur pada titik yang dijadikan markaz di pusat kota (pada saat itu). Waktu ihtiyath diperlukan untuk mengantisipasi daerah di sebelah baratnya (daerah sebelah timur mengalami/memasuki awal waktu salat lebih dahulu atau lebih awal daripada daerah yang di sebelah baratnya).

Dalam penentuan data lintang dan bujur suatu kota; biasanya setelah kota tersebut mengalami perkembangan maka terjadilah perluasan kota dan tidak mustahil pusat kota dulunya kemudian berubah menjadi pinggiran kota. Akibat dari perkembangan ini maka ujung timur atau ujung barat kota akan mempunyai jarak yang cukup jauh dari titik penentuan lintang dan bujur kota semula. Maka jika hasil akhir perhitungan awal waktu salat tidak ditambahkan waktu ihtiyath, ini berarti hasil perhitungan tersebut hanya berlaku untuk daerah titik markaz dan daerah di sebelah timurnya saja, tidak berlaku untuk 
daerah di sebelah baratnya (daerah sebelah timur mengalami waktu lebih dahulu daripada daerah yang disebelah baratnya). Ihtiyath itu merupakan bentuk pengamanan pada perhitungan awal waktu salat agar seluruh kota; termasuk juga mereka yang bermukim di sebelah baratnya dalam melaksanakan salat sudah benar-benar masuk waktunya. Sebagaimana dijelaskan sebelumnya bahwa terdapat kalangan pesantren tertentu tidak mencantumkan waktu ihtiyath dalam jadwal salat yang dibuatnya. Pelaksanaan azan sebagai pertanda masuknya awal waktu salat dilaksanakan sesuai dengan waktu yang sebenarnya. Jadwal yang dibuatnya ini hanya bersifat internal; hanya diberlakukan di pondok pesantren yang bersangkutan. Menurut hemat penulis, sebaiknya tetap digunakan waktu ihtiyath dalam perhitungan jadwal salat. Di samping untuk fungsi-fungsi yang telah diuraikan sebelumnya, waktu ihtiyath ini penting untuk mengantisipasi misalnya ketidakakuratan jam yang dipakai. Jangan sampai karena kekeliruan jam yang dipakai, suatu ibadah dilaksanakan sebelum masuk waktunya. Tentunya ibadah tersebut menjadi tidak sah.

d. Bisanya sebuah jadwal salat untuk suatu kota juga dipergunakan oleh daerah di sekitarnya yang berdekatan dan tidak terlalu jauh jaraknya. Seperti jadwal salat untuk kota kabupaten dipergunakan oleh kota-kota kecamatan sekitarnya. Agar tidak terjadi kekeliruan dalam penentuan awal waktu salat bagi daerah di sekitar kota peruntukannya, jadwal salat tadi diperlukan waktu ihtiyath. ${ }^{35}$

e. Mengcover daerah yang memiliki tekstur ketinggian yang berbeda antara satu sisi dengan sisi lainnya. Waktu Ihtiyath untuk mengatisipasi kota yang teksturnya tidak datar; ada bagian kota yang terdiri dari dataran tinggi sedangkan bagian yang lainnya adalah dataran rendah. Perimbangan waktu untuk kedua bagian kota tersebut (agar salat tersebut tidak lebih cepat atau terlalu lambat). Ketinggian tempat ini terkait dengan $\mathrm{h}$ (ketinggian) Mata hari; terbit dan atau terbenam Mata hari di suatu tempat). Pada daerah dataran tinggi, akan menyaksikan atau mengalami saat Mata hari terbenam belakangan dibandingkan mereka yang tinggal di daerah dataran rendah. Dan akan menyaksikan atau mengalami saat Mata hari terbit lebih dahulu dibandingkan mereka yang tinggal di daerah dataran rendah. Terkait dengan ketinggian tempat ini terdapat perbedaan pendapat di kalangan ahli ilmu Falak, sebagai berikut:

1). Ketinggian tempat itu diukur dari permukaan laut. Terlepas daerah atau tempat tersebut teksturnya datar atau mungkin merupakan perbukitan/dataran tinggi. ${ }^{36}$

2). Daerah tersebut merupakan perbukitan/dataran tinggi

35 Ibid, h. 37-38

36 Jika suatu daerah itu teksturnya datar walaupun ia merupakan daerah yang berada pada dataran tinggi (dihitung dari permukaan laut), maka ketinggian daerah tersebut tidak berpengaruh pada perhitungan kerendahan ufuk karena ufuk di tempat atau daerah tersebut relatif datar. Namun pada daerah perbukitan/dataran tinggi, maka akan memiliki ufuk yang lebih rendah. 
sehingga memiliki ufuk yang lebih rendah. Ini berdampak pada ketinggian Mata hari pada waktu terbit atau terbenam. Seperti kota Semarang; daerah bagian utaranya dataran rendah karena berada di dekat pantai sedang daerah selatannya merupakan daerah perbukitan. Pendapat ini yang dipilih oleh badan Hisab Rukyat Kota Bandung dalam salah satu rilisnya.

Besaran nialai ihtiyath dalam perhitungan awal waktu salat harus mempertimbangkan:

a. Luas daerah atau kota yang dihitung awal waktu salatnya. Terkait dengan luas daerah atau kota yang dihitung awal waktu salatnya dapat dijelskan sebagai berikut:

1). Besaran ihtiyath harus mengcover daerah atau kota yang dihitung awal waktu salatnya. Semakin luas suatu kota atau daerah, tentu semakin besar nilai ihtiyathnya.

2). Demikian juga daerah atau kota yang relatif kecil tentu saja nilai ihtiyathnya juga kecil.

b. Acuan koordinat kota atau daerah yang dijadikan patokan perhitungan. Acuan koordinat suatu kota atau daerah itu terkadang berbeda-beda. Antara koordinat yang digunakan pemerintah daerah, ahli Falak, dan lembagalembaga lainnya tidaklah sama. Hal ini karena acuan atau patokan yang digunakan berbeda-beda. Misalnya untuk kota Bandar Lampung ada yang menjadikan satu titik di daerah Teluk Betung sebagai acuan karena dulunya pusat kota Badar Lampung, ada yang menjadikan Kantor Gubernur sebagai acuan, ada yang menjadikan Patung
Adipura sebagai acuan karena telah menjadi landmark kota Bandar lampung, dan sebagainya.

Koordinat yang diajdikan acuan untuk suatu kota atau daerah ini berpengaruh terhadap nilai ihtiyath dalam perhitungan awal waktu salatnya. Hal ini dapat dijelaskan sebagai berikut: a. Apabila acuan koordinat daerah atau kota yang dihitung awal waktu salatnya terletak di sisi timur kota atau daerah tersebut, maka nilai ihtiyath yang harus berikan lebih besar untuk mengcover daerah atau kota yang di sebelah atau sisi barat.

b. Sebaliknya apabila koordinat yang enjadi acuan suatu daerah atau kota itu terletak di sisi sebelah baratnya, maka ihtiyath yang dibutuhkan cenderung lebih kecil.

\section{Kesimpulan}

Dari paparan sebelumnya, dapatlah kita simpulkan sebagai berikut:

1. Ulama Falak Tradisional dan ulama Dahulu cenderung memberikan nilai ihtiyath dalam perhitungan awal waktu yang besar. Hal ini karena jadwal salat yang mereka hisab cenderung untuk daerah atau kota tersebut dan daerah sekitarnya. Sedang ulama Falak Sekarang memberikan nilai ihtiyath yang lebih kecil dengan pertimbangan keutamaan salat di awal waktu.

2. Besaran ihtiyath dalam perhitungan awal waktu salat harus mempertimbangkan:

a. Luas daerah atau kota yang dihitung awal waktu salatnya.

c. Acuan koordinat kota atau daerah yang dijadikan patokan perhitungan. 


\section{Daftar Pustaka}

Ahmad SS, Noor, Syawariq al-Anwar, Kudus: madrasah Tasywiq athThullab Salafiyah

Badan Hisab Rukyat Depag, 1981, Almanak Hisab Rukyat, Jakarta: Proyek Pembinaan Badan Peradilan Agama Islam

Depag RI, 1994, Pedoman Penentuan Jadwal Waktu Salat Sepanjang Masa, Jakarta: Depag RI

Djambek, Sa'adoeddin, 1974, Salat dan Puasa di Daerah Kutub, Jakarta: Bulan Bintang

, 1974 a, Pedoman Waktu Salat Sepanjang Masa, Jakarta: Bulan Bintang

Khazin, Muhyiddin, 2008, Ilmu Falak Dalam Teori dan Praktik, Yogyakarta: Buana Pustaka „99 Tanya Jawab Masalab Hisab \& Rukyat, Yogyakarta: Ramadan Press

Jayusman dkk, Jadwal Imsakiah Ramadan 1430 H Untuk Kota Bandar Lampung, Penelitian Kompetitif, IAIN Raden Intan 2010

M. Muslih, 1997, Peneapan Lintang dan Bujur Kab Dati II Batang (Tabkik. di Pusat Kota Dan Pengarubnya Terbadap Arah Kiblat, Waktu Salat, dan Ibtiyath), Pekalongan: STAIN Pekalongan

Moeid, el-, Ibnoe Zahid Abdo, Jadwal Imsakiah Ramadan 1430 H untuk Kota Bandar Lampung, geocitis.com diakses pada tanggal 6 November 2009
Belajar Ilmu Hisab,
http://rukyatulhilal.org/ diakses
pada tanggal 4 Maret 2010

Rusyd, Ibnu, Bidayahal-Mujtahid, T.Tp: Dar al-Fikr, T.th

Sabiq, Sayyid, Fiqh as-Sunnah, juz I, Dar al Fath-Kairo, cet. II, 1419 $\mathrm{H} / 1999 \mathrm{M}$

Supriatna, Encup, 2007, Hisab Rukyat dan Aplikasinya, Bandung: Refika Aditama

Syaukani, asy-, Muhammad bin Ali, Naylul Awthar, Kairo: Dar Ibnul Haitsam, tt.

T Djamaluddin, Posisi Matahari Dan Penentuan Jadwal Salat, http://tdjamaluddin.spaces.live.com diakses 15 November 2009

Tim Majelis Tarjih dan Tajdid Pimpinan Pusat Muhammadiyah, Pedoman Hisab Muhammadiyah, Yogyakarta: Majelis Tarjih dan Tajdid Pimpinan Pusat Muhammadiyah, 2009, cet.ke-2

Waktu Sholat, http://www.alhusiniyah.com diakses pada tanggal 15 November 2009

Zuhaili, az, Wahbah, tt, al-Figh al-Islami wa Adillatuh, Jilid I, Dimsyiq: Dar al-Fikr 